\title{
The Effect of Carbofuran on Testosterone Serum Concentration and Histological Change of Leydig Cell in Mice
}

\author{
Osama Eshtewi A. Elayan ${ }^{1}$, Setyawati Karyono ${ }^{2}$, Hidayat Sujuti ${ }^{3}$ \\ ${ }^{1}$ MEDICINE, INTERESTS IN TOXICOLOGY / University Of BRAWIJAYA ,Indonesia ,Malang)
}

\begin{abstract}
Carbofuran (Furadan) is a broad spectrum carbamate pesticide that kills insects, mites, and nematodes on contact or after ingestion. It has a potential to cause damage to the reproductive system and to health by prolong exposure. The widespread of pesticide in public health and agriculture has caused severe environmental pollution and health hazards. This study describes the effects of furadan on male reproductive organ of the mice. The animals $(n=20)$ were grouped a (control), I, II, and III C (experimental).The experimental animals of group I were administered with $0.1 \mathrm{mg} / \mathrm{Kg}$ body weight/day carbofuran in saline for 30 days, group II were administered with $0.2 \mathrm{mg} / \mathrm{Kg}$ body weight/day carbofuran in saline for 30 days and III were administered with $0.4 \mathrm{mg} / \mathrm{Kg}$ body weight/ day carbofuran in saline for 30 days and then we see the effect on testosterone serum concentration by using ELISA method and leydig cells were fixed and processed to examine the histological changes.

Keywords: Optical microscope, Furadan, Toxicity, Testosterone, Leydig cells
\end{abstract}

\section{INTRODUCTION}

The competition between the insects and human has been there ever since beginning of civilized mankind. Pest suppression with synthetic chemicals is the quickest and surest method of pest management. However, there are serious ecological and environmental problems with over reliance on pesticides. Persistence of pesticides in the food chain (Carson 1962) and the development of resistance in the pests towards pesticides (Brown 1980) are the two serious problems encountered. In 1945 the first soil-acting carbamate herbicides were discovered by British workers and the organochlorine insecticides, chlordane was introduced in USA and in Germany. There is a lot of concern about the health hazards and the chronic effects of pesticides.

Carbofuran (2,3-dihydro-2,2-dimethyl-7-benzofuranyl methylcarbamate) generally called as furadan is a broad spectrum carbamate pesticide that kills insects, mites, and nematodes on contact or after ingestion. Carbofuran is highly toxic by inhalation and ingestion and moderately toxic by dermal absorption. As with other carbamate compounds, carbofuran's cholinesterase-inhibiting effect is short-term and irreversible. Carbofuran is highly toxic to fish and birds particularly in granular form, which birds often eat mistakenl for seeds, or through contaminated drinking water.

Pesticides may induce oxidative stress, leading to generation of free radicals and alteration in antioxidants, oxygen free radicals, the scavenging enzyme system, and lipid peroxidation.

This study was designed to see the sub acute toxic effects of carbofuran on testosterone and leydig cells, one of the male reproductive organs which play a vital role in male fertility.

\subsection{Materials And Methods}

Adult male mice $(\mathrm{n}=20$ ), each weighing between 25 -30 grams, were taken from the pharmacological laboratory in the medical faculty of Brawijaya University in Malang. The animals were divided into four groups as $\mathrm{A}, \mathrm{B}, \mathrm{C}$ and $\mathrm{D}$ each comprising of five animals. Five animals of each subgroup were kept in one cage. Animals of group A (control) were given normal saline orally for a period of one month. The experimental animals of group B were administered with $0.1 \mathrm{mg} / \mathrm{Kg}$ body weight/ day carbofuran in saline for 30 days, group $\mathrm{C}$ were administered with $0,2 \mathrm{mg} / \mathrm{kg}$ body weight/day carbofuran in saline for 30 days and group D were administered with $0,4 \mathrm{mg} / \mathrm{kg}$ body weight/day carbofuran in saline for 30 days. After finish experiment time (30 days) we will take serum blood from mice to see the concentration of testosterone by ELISA method. The leydig cells were carefully dissected and removed. The tissues were fixed in $10 \%$ formaline, embedded in paraffin and $5 \mathrm{um}$ sections were cut and stained with haematoxylin and eosin stain. The tissue sections were observed under a research light microscope for qualitative changes in leydig cells.

\section{RESULT}

In the Figure 1 below with increasing doses of carbofuran increasingly high then drop down to the more testosterone so changes occur because decreased testosterone dose escalation. 
Control Group mice showing the leydig cells in the microscope with out tratment by carbofuran,where the leydig cell was seen in normal number. (Figure 2)

\section{Group I (experimental)}

Group I mice after treatment by $0.1 \mathrm{mg} / \mathrm{kg} . b w /$ day carbufuran showing an increase in leydig cells number if compared with the above figure of leydig cells with out treatment by carbofuran. (Figure 3)

\section{Group II (experimental)}

Group II mice after treatment by $0.2 \mathrm{mg} / \mathrm{kg} . \mathrm{bw} /$ day carbofuran, indicate the change in the concentration of carbofuran dosing will lead to proliferation of leydig cell number and decease in the leydig cell function. (Figure 4)

\section{Group III (experimental)}

Group III mice after treatment by $0.4 \mathrm{mg} / \mathrm{kg} . \mathrm{bw} / \mathrm{day}$ carbofuran showing the increase number of Leydig cell where an increasing dose variation will look more suffered damage and was seen in the fourth image. Where the function with carbofuran dose $0.4 \mathrm{mg} / \mathrm{kg}$ increased cell ledydig number but the effect of cell function leydiq to testosterone decline. (Figure 5)

In the Figure 6 below with increasing doses of carbofuran increasingly high that increased Leydig cell but the effects of Leydig cell testosterone will eventually reduce and destroy.

\section{Discussion}

Carbofuran (Furadan) has the potential to cause damage to the reproductive system by prolonged exposure. The male reproductive organs are severely damaged at doses $0.4 \mathrm{mg} / \mathrm{kg}$ bw in mice. The effects include decrease in testosterone serum concentration and proliferation of leydig cells number. It has been shown to produce developmental toxicity in several doses, which cause reproductive system toxicity.

We note that group III, which treated by $0.4 \mathrm{mg} / \mathrm{Kg}$ body weight/ day carbofuran has the highest rate of effect compared to other groups, followed by group C, and group B. This means the carbofuran at high dose lead to high decrees on testosterone serum concentration and on the histological leydig cell where the effect on leydig cell at high dose of carbofuran led to proliferation and this seen in microscope more when the dose increased. On premises inspection microscope is seen that with increasing the dose of the Leydig cell damage will be even greater.

The dramatic increase in the use of carbamate compounds substitutes for chlorinated hydrocarbon insecticides has resulted in a new dimension of occupational hazard for agriculture industry Chronic administration of carbofuran lead to significant histological changes in male reproductive organs like leydig cells as documented by previous and present study.

The spermatogenesis in mammals depends on testosterone production by Leydig cells in response to stimulation by FSH and LH. FSH increases Sertloi cell synthesis of an androgen binding protein needed to maintain high concentrations of testosterone. LH stimulates testosterone production by the interstitial cells of the testis. The hormonal changes produced by carbofuran compounds favour direct toxic effect of insecticide or possibly through a change in the neuroendocrine environment resulting into acetyl cholinestase inhibition.

The effect on germ cells might be due to the decrease in testosterone level resulting due to injury of the cells of Leydig .

Androgens from adrenal glands and testes control development, maintenance, growth and secretory functions of prostate. Interaction of androgens with prostatic epithelium, stroma, neuroendocrine cells, other hormones and growth factors form a complex system designed to regulate not only prostatic growth but also relative number of epithelial and non-epithelial cells. Loss or decrease in the level of testosterone will lead to involution and apoptosis of prostate. The effects of estrogen and testosterone on sex accessory glands are antagonist. So increase in estrogen as a result of decrease or absence of testosterone will increase the fibromuscular tissue of prostate, this lead to degeneration of glandular epithelium and increase in fibromuscular tissue due to decrease in the level of testosterone as a result of direct toxic effects of furadan on Leydig cells and Sertoli cells in response to stimulation by LH and FSH respectively.

As it is clear from the results of this study that the administration of furadan (methomyl carbamate 0.1, 0.2 and $0.4 \mathrm{mg} / \mathrm{Kg}$ body weight in saline) to the mice daily for one month has shown histological changes in leydig cell and this change lead to effect in leydig cell function causing to decrease in testosterone serum concentration, it will result into male infertility. 


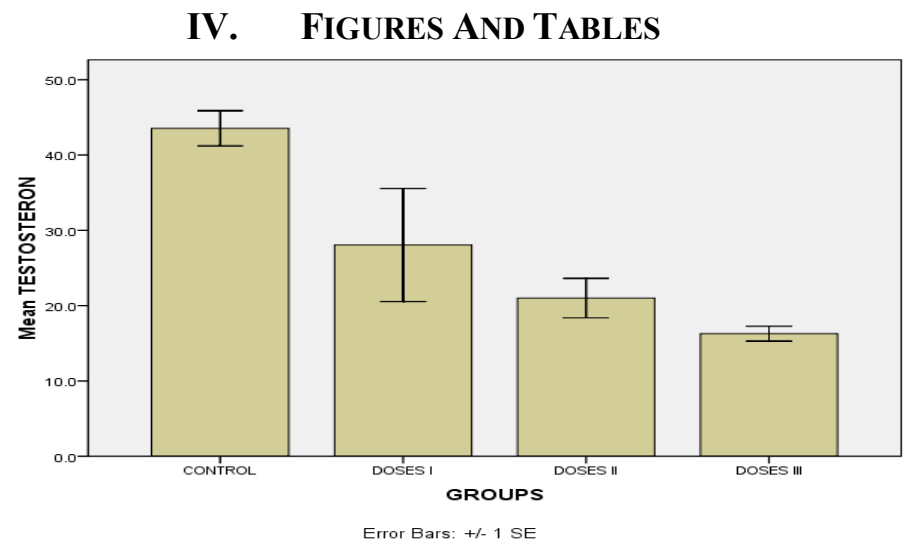

Figure 1: Bar Graph of mean of testosterone for each group

Control : Control group with normal saline

Grp I : Carbofuran with doses $0.1 \mathrm{mg} / \mathrm{kg} . b w /$ day

Grp II : Carbofuran with doses $0.2 \mathrm{mg} / \mathrm{kg} . b w / \mathrm{day}$

Grp III : Carbofuran with doses $0.4 \mathrm{mg} / \mathrm{kg} . \mathrm{bw} / \mathrm{day}$

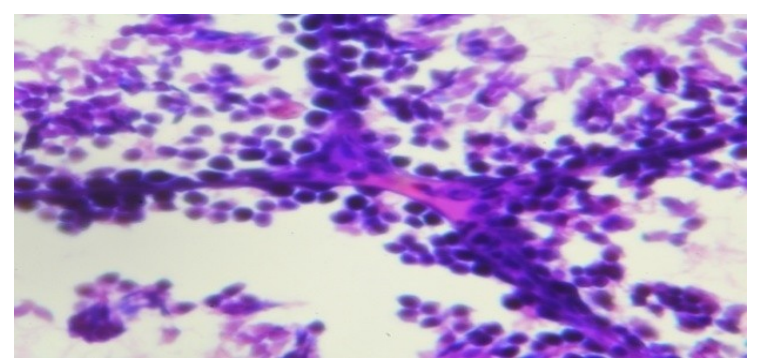

Figur 2: Normal leydig cell (by miscrocope)

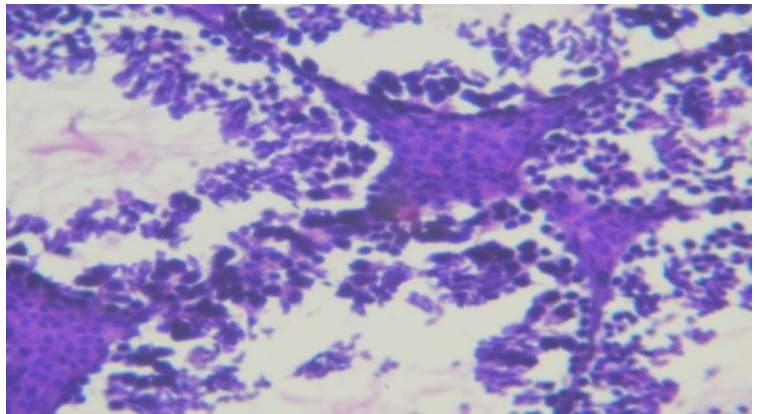

Figure 3: Effect of dose carbofuran in $0.1 \mathrm{mg} / \mathrm{kg.bw} / \mathrm{day}(\mathrm{by}$ miscrocope)

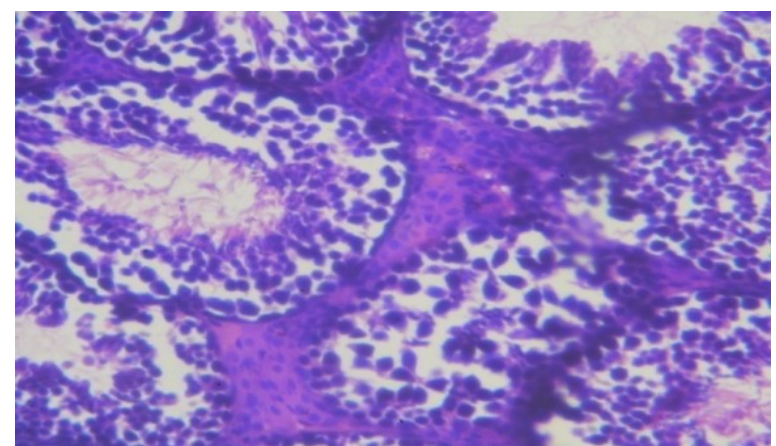

Figure 4: Effect of dose carbofuran $0.2 \mathrm{mg} / \mathrm{kg} . \mathrm{bb} / \mathrm{day}(\mathrm{by}$ miscrocope) 


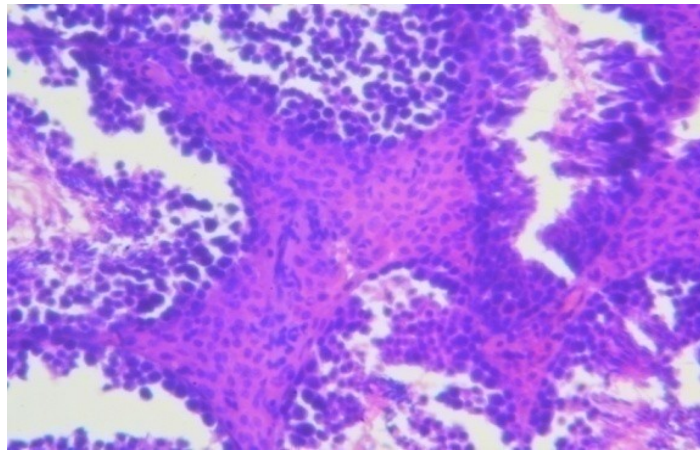

Figure 5: Effect of dose carbofuran $0.4 \mathrm{mg} / \mathrm{kg} . \mathrm{bb} / \mathrm{day}(\mathrm{by}$ miscrocope)

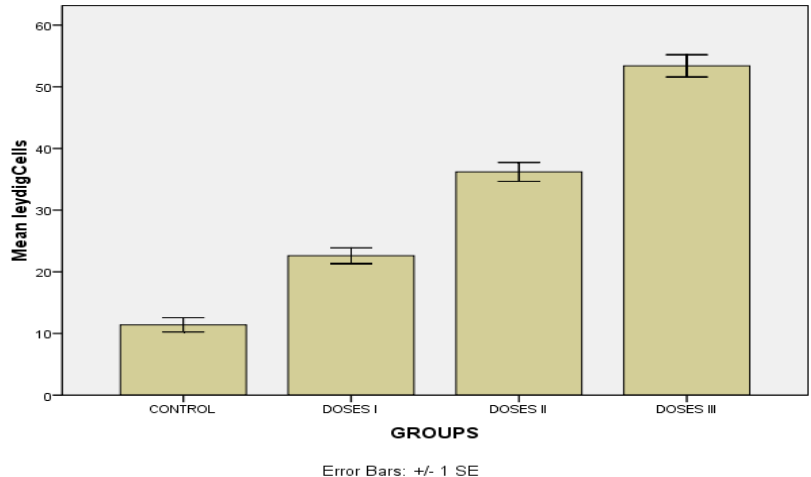

Figure 6: Bar Graph of mean of leydig cell for each group

Control : Control group with normal saline

Grp I : Carbofuran with doses $0.1 \mathrm{mg} / \mathrm{kg} \cdot \mathrm{bw} / \mathrm{day}$

Grp II : Carbofuran with doses $0.2 \mathrm{mg} / \mathrm{kg} . \mathrm{bw} / \mathrm{day}$

Grp III : Carbofuran with doses $0.4 \mathrm{mg} / \mathrm{kg} . b w /$ day

\section{CONCLUSION}

It is concluded from present study that the use of insecticide N-Methyl carbofuran (furadan) at the dose of $0.1,0.2$, and $0.4 \mathrm{mg} / \mathrm{Kg}$ body weight in saline orally for 30 days is responsible for irreversible damage to male reproductive organs if precautionary measures are not taken while using them. Hyper proliferation to leydig cells lead into decrease testosterone serum concentration leading to infertility. So in selecting a safe pesticide, quantities and mode of usage must be strictly monitored to minimize the possibility of exposure of non target organisms to injurious quantities of these chemicals.

This can be achieved through public health education to make people aware of the hazardous effects of these compounds. It is therefore recommended that great precautions must be taken to minimize the harmful side effects of such chemicals to the environment especially to men, animals and agriculture products aiming to avoid environmental pollution. The precautionary measures like wearing of impermeable gloves and masks to reduce the risk of inhalation of spray should be implemented.

\section{REFERENCES}

[1] Banerjee BD, Seth V, Battacharya A, Pasha ST, Chakrabory AK (1999). Biochemical effects of some pesticides on lipid peroxidation and free radical scavengers. Toxicol Lett 107: 33-47.

[2] Baron RL (1991). Carbamates insecticides. In: Handbook of pesticide Toxicology. Hays WJ, Laus ER, eds, San Diego: pp 112590.

[3] Brown, W.R. (1980). 2-Year dietary toxicity and carcinogenicity study in mice with technical carbofuran. Act No. 150.52 Histopathology Part. Unpublished report prepared by Research Pathology Services, Inc. PA,USA. Submitted to WHO by FMC Corp., Philadelphia, PA, USA.

[4] Carson, R. (1962). Silent Spring. Houghton Mifflin, Boston, MA, pp. 368.

[5] Etemadi-Aleagha A, Akhgari M, Abdollahi M. (2002). A brief review on oxidative stress and cardiac diseases. Mid East Pharmac.10: 8-9.

[6] Kackar R, Srivastara MK, Raizada RB. (1997). Induction of gonadal toxicity to male rats after chronic exposure to mancozob. Ind. Health. 35: 104-11.

[7] Sugar J (1997). Electron microscopic study of acid phosphatase and cell organelles duringhuman and experimental skin carcinogenesis. Acta. Morpho. Acad Sci. 15: 93-8.

[8] Mitchell RN, Cotran RS (1997). Cell injury death and adaptation.In: Basic pathology. 6th edn. Kumar V, Ramz S,Robbins SL, eds. Philadelphia: WB Saunders. Pp 3-24. 